\title{
STORAGE OF 'SWINGLE' CITRUMELO SEEDS IN DIFFERENT MATURATION STAGES SUBJECTED TO FUNGICIDE TREATMENT ${ }^{1}$
}

\author{
TANISMARE TATIANA DE ALMEIDA SILVA², RENATO MENDES GUIMARÃES ${ }^{3}$, \\ ÉDILA VILELA DE RESENDE VON PINHO ${ }^{4}$, LUCIANA APARECIDA DE SOUZA ABREU ${ }^{5}$
}

\begin{abstract}
The establishment of citrus orchards with rootstocks from seed with a low physiological quality has been a recurring problem. Low quality seeds directly affect both the final stand and the time required for seedling production. The irregular maturation of fruits, seed recalcitrance, and the high incidence of fungi, make long term storage difficult, even at low temperatures. This study evaluated the storage potential and the use of fungicide treatments on 'Swingle' citrumelo seeds extracted from fruits collected at two maturation stages, green or ripe. The seeds were subjected to a thermal treatment, treated with Derosal, Thiram or Tecto+Captan fungicides, packaged in impermeable polyethylene bags and stored in a cold chamber for nine months. Every three months, the physiological and sanitary qualities of the seeds were evaluated from germination and sanitary tests and also from enzyme profiles. Seeds from green fruits deteriorated less than those from mature fruits; deterioration increased up to nine months of storage; treatment with the Tecto+Captan mixture gave effective pathogen control and maintained seed quality during storage. The germination of the green and ripe seeds is satisfactory ( $70 \%)$ after three months storage.
\end{abstract}

Index terms: 'Swingle' citrumelo, physiology, seed health, conservation.

\section{ARMAZENAMENTO DE SEMENTES DE CITRUMELO 'SWINGLE' EM DIFERENTES ESTÁDIOS DE MATURAÇÃO SUBMETIDAS A TRATAMENTOS FUNGICIDAS}

\begin{abstract}
RESUMO - A formação de pomares com porta-enxertos oriundos de sementes de baixa qualidade fisiológica tem sido um entrave, pois essas influenciam diretamente o estande final e o tempo para a formação de mudas. A desuniformidade de maturação dos frutos, o caráter recalcitrante dessas sementes e a alta incidência de fungos dificultam o armazenamento à longo prazo, mesmo em condições de baixa temperatura. Objetivou-se com a pesquisa investigar o potencial de armazenamento e a utilização de tratamentos fungicidas em sementes de citrumelo 'Swingle', extraídas de frutos colhidos em dois estádios de maturação, verde e maduro. As sementes foram submetidas ao tratamento térmico e, posteriormente tratadas com Derosal, Thiram e Tecto+Captan, embaladas em sacos de polietileno impermeáveis e armazenadas em câmara fria por nove meses. Em intervalos trimestrais, a qualidade fisiológica e sanitária das sementes foi avaliada por meio dos testes de germinação, sanidade e perfis enzimáticos. As sementes obtidas de frutos verdes
\end{abstract}

\footnotetext{
${ }^{1}$ Submetido em 11/10/2010. Aceito para publicação em 14/01/2011. Parte da Dissertação de Mestrado em Fitotecnia pelo primeiro autor.

${ }^{2}$ Eng. Agr., DSc., Lavras, MG; e-mail: mareagro@bol.com.br, Caixa Postal 3037, CEP: 37200-000, Lavras-MG.
}

${ }^{3}$ Eng.Agr., DSc., Prof. Titular do Departamento de Agricultura da UFLA; e-mail: renatomg@ufla.br, Caixa Postal 3037, CEP: 37200-000, Lavras-MG.

${ }^{4}$ Eng.Agr., DSc., Prof. Titular do Departamento de Agricultura da UFLA; e-mail: edila@ufla.br, Caixa Postal 3037,CEP: 37200-000, Lavras-MG.

${ }^{5}$ Eng.Agr., DSc., Lavras, MG; e-mail: luapsouza2003@yahoo.com.br, Caixa Postal 3037, CEP: 37200-000, Lavras-MG. 
deterioram-se menos que as de frutos maduros, sendo a deterioração crescente até nove meses de armazenamento; o uso da mistura Tecto+Captan é eficiente no controle de patógenos e mantém a qualidade das sementes e ao três meses de armazenamento a germinação das sementes verdes e maduras é satisfatória (70\%).

Termos para indexação: citrumelo'Swingle', fisiologia, sanidade de sementes, conservação.

\section{INTRODUCTION}

Citrus orchards are established mostly with rootstocks and the use of certified and healthy seedlings is becoming mandatory due to the incidence of pathogens. 'Swingle' citrumelo has come into evidence as a rootstock since it is resistant to the major diseases occurring in citrus orchards, and this has increased the demand for seedlings grafted onto this rootstock (Junior, 2005). The ideal moment for harvesting citrumelo fruits is not easily determined and fruit maturation is irregular, making the purchase of vigorous seeds difficult (Rena et al., 2005).

'Swingle' citrumelo seeds are considered recalcitrant and are slow to germinate, requiring the removal of the tegument before sowing to accelerate and standardize the germination process (Cohen, 1956). In general, seeds are stored at $35 \%$ moisture content, which permits fungi growth, and fungicide seed treatment is necessary to maintain seed viability and reduce deterioration.

Part of the phenomenon of seed deterioration is a consequence of damage caused by free radicals and is controlled by enzyme systems, including superoxide dismutase (SOD), catalase (CAT) and peroxidase (PO), glutamate oxalo-acetate transaminase (GOT), malate dehydrogenase (MDH), esterase (EST), phosphate glutamate isomerase (Aug and McDonald, 1995). Their study can contribute to understanding the production technology necessary for obtaining vigorous seeds and increasing storage time, which is a current demand for high quality seedling production systems.

The available literature on citrus seeds is scarce and due to the importance of rootstock use in citrus and the diversity of the genus Citrus, there is an urgent need for research in this area. This study investigated the storage potential and use of fungicide treatments on 'Swingle' citrumelo seeds extracted from fruits at two development stages.

\section{MATERIAL AND METHODS}

The research was carried at the Federal University of Lavras, in 2005. Seeds of 'Swingle' citrumelo (Citrus paradise Macfad. cv. Duncan x Poncirustrifoliata (L.) Raf.) were mechanically extracted from fruits at two maturation stages (green and ripe) and subjected to thermal treatment at $52{ }^{\circ} \mathrm{C}$ for ten minutes in a water bath. Green seeds were considered as those originating from fruits with dark green rinds with a white pulp and light yellow colored seeds (Stage 1), whereas mature seeds were those from fruits with a yellow rind, a creamy-yellow pulp and a dark yellow tegument (Stage 2).

The seeds were divided into two lots (lot stage 1 and 2 ) and each was subjected to different chemical treatments: Captan+Tecto 600 (30 g+10 g/20 L seed), Thiram (2 g/kg seed), Derosal ( $2 \mathrm{~g} / \mathrm{kg}$ seed) and an untreated control. After the chemical treatment, the seeds were stored for three, six, and nine months in polyethylene bags in a cold, dry chamber at $10^{\circ} \mathrm{C}$.

Every three months, the seed water contents were determined in an oven at $105{ }^{\circ} \mathrm{C} \pm 3{ }^{\circ} \mathrm{C}$ for 24 hours, according to the Regras para Análise de Sementes (Brasil, 1992). Before sowing, and after each storage period, the tegument was extracted. One liter of water was added to one liter of seeds in a bucket; subsequently, $0.5 \mathrm{~L}$ of $12 \%$ sodium hypochloride $(\mathrm{NaClO}), 18 \mathrm{~g}$ of sodium hydroxide $(\mathrm{NaOH})$ and $5 \mathrm{~mL}$ of hydrochloric acid $(\mathrm{HCl})$ were added. The mixture was stirred continuously for five minutes and then the seeds were allowed to settle for 40 minutes until they developed a whitish aspect and the tegument could be easily removed. The seeds where washed in a lime solution (200 $\mathrm{g}$ lime/ $5 \mathrm{~L}$ water) and after this process the tegument was manually removed.

Seed quality was evaluated as follows: Germination - sowing on Germitest-paper, moistened with distilled water up to 2.5 times the dry paper's weight. The seeds 
were placed in a germinator at $25{ }^{\circ} \mathrm{C}$ and counts were made 15 and 30 days after sowing. Normal seedlings were considered as those having an exposed leaflet and primary roots at least $3 \mathrm{~cm}$ long. Four replicates of 50 seeds were used and the results expressed as the percentage of normal seedlings (Carvalho, 2001). Health test: the test was done in $15 \mathrm{~cm}$ Petri dishes containing two sheets of autoclaved filter paper and moistened with sterile distilled water. Four hundred seeds were analyzed per treatment, distributed in eight replicates of 25 seeds each, with 200 seeds having their tegument removed as described above for the germination test and the other 200 remaining intact. Subsequently, the dishes were placed in an incubator at $20{ }^{\circ} \mathrm{C}$, with a daily twelve hour lighting periods for seven days. After the incubation period, both the identification and quantification of the fungi present on the seeds were made (Machado, 1988). Enzyme extraction and analysis - For the 0, 3, 6, and 9 month storage periods, two samples of 50 seeds without teguments were removed from each treatment, and ground up in a mortar over ice, in the presence of PVP and liquid nitrogen and then stored at -86 ${ }^{\circ} \mathrm{C}$. Enzyme extraction was done with $0.2 \mathrm{M} 8.0+0.1 \%$ $\beta$-mercaptoethanol, at a concentration of $250 \mu \mathrm{L}$ per 100 $\mathrm{mg}$ seeds. The material was homogeneized in a vortex shaker and maintained in a refrigerator overnight, followed by centrifugation at $16,000 \mathrm{xg}$ for 60 minutes at $4{ }^{\circ} \mathrm{C}$. The electrophoresis was run in a system of polyacrilamide gels at $7.5 \%$ (separator gel) and $4.5 \%$ (concentrator gel). The gel/electrode system used was Tris-glycine $\mathrm{pH}$ 8.9. Fifteen $\mu \mathrm{L}$ of the sample supernatants were applied and the run performed at $150 \mathrm{~V}$ for 4 hours. After the separation, the gels were revealed for the enzymes: catalase (CAT), esterase (EST), glutamate oxalacetate transaminase (GOT), malate dehydrogenase $(\mathrm{MDH})$, phosphate glutamate isomerase (PGI) and superoxide dismutase (SOD), as described by (Alfenas et al. 1991).

The experimental design was completely randomized, in a $2 \times 4 \times 4$ factorial, with 2 maturation stages (green and mature seeds), four chemical treatments (untreated control, Tecto+Captan, Thiram or Derosal) and four storage times (0, 3, 6, and 9 months). The data were submitted to an analysis of variance and the means compared by the Tukey test at the 5\% probability level.

\section{RESULTS AND DISCUSSION}

After nine months storage, there was about $6 \%$ increase in the seed water content values, regardless of the fungicide treatment or seed maturation (Table 1). Von Pinho et al. (2005) stored 'Swingle' citrumelo seeds in impermeable plastic bags and found that the water contents remained unchanged after the third month of storage and that there was a reduction in the water contents of seeds stored in semipermeable and permeable bags. Bonome (2006) observed an increase in the water content of rubber tree seeds during storage in impermeable packages, suggesting that this increase was a result of the package type, associated with the high water content when the seeds were stored. This factor contributed to an increase in seed metabolic activity and, consequently, in the respiration rate, resulting in higher $\mathrm{CO}_{2}$ and water vapor liberation inside the packaging. Another factor that may have contributed towards the increase in moisture content was the presence of pathogens.

TABLE 1. Seed moisture (\%) of 'Swingle' citrumelo seeds from green (Stage 1) and ripe (Stage 2) fruits during storage.

\begin{tabular}{ccc}
\hline & \multicolumn{2}{c}{ Seed moisture $(\%)$} \\
\hline $\begin{array}{c}\text { Storage time } \\
\text { (months) }\end{array}$ & Stage 1 & Stage 2 \\
0 & 37.40 & 38.50 \\
3 & 39.50 & 40.60 \\
6 & 41.50 & 42.70 \\
9 & 43.50 & 44.70 \\
\hline
\end{tabular}

The most common fungi found on 'Swingle' citrumelo seeds were Aspergillus, Fusarium, and Penicillium, but also with less than $1 \%$ of Alternaria, Rhizopus, Drecherela, Trichoderma, Phoma and Nigrospora. The presence of pathogens from the genera Aspergillus, Fusarium and Penicillium was observed on stage seeds (Table 2) before storage. Seed treatment with the fungicide mixture Captan+Tecto inhibited the occurrence of these pathogens. The fungicide Derosal was effective for pathogen control, except for those of the genera Fusarium in seeds with no tegument, and for Penicillium on seeds with a tegument. In contrast, Thiram controlled only Penicillium on seeds with no tegument (Table 2).

At three months storage, seed treatment with Captan+Tecto and Thiram only controlled Fusarium in seeds with tegument. Camacho et al. (1995) observed 
effective pathogen control in the citrus species analyzed when chemical control was done with Thiram and Benomyl. The presence of Fusarium and Penicillium at six months' storage was similar to that observed at the three month evaluation. Aspergillus sp. was observed at this evaluation, and it was controlled only with the fungicide mixture Captan+Tecto. After nine months of storage, seed treatment with Captan+Tecto was effective for the control of the pathogens, except for seeds with no tegument infected by Penicillium.

TABLE 2. Incidence, presence (p) or absence (a), of fungi on 'Swingle' citrumelo seeds (Stage 1 and Stage 2) with (WT) and without tegument (NT) during storage.

\begin{tabular}{|c|c|c|c|c|c|c|c|c|c|c|c|c|c|}
\hline \multirow{3}{*}{$\begin{array}{l}\text { Storage time } \\
\text { (months) }\end{array}$} & \multirow{3}{*}{ Fungicide } & \multicolumn{6}{|c|}{ Stage 1} & \multicolumn{6}{|c|}{ Stage 2} \\
\hline & & \multicolumn{2}{|c|}{$* A s p$} & \multicolumn{2}{|c|}{ Fus. } & \multicolumn{2}{|c|}{ Pen. } & \multicolumn{2}{|c|}{ Asp. } & \multicolumn{2}{|c|}{ Fus. } & \multicolumn{2}{|c|}{ Pen. } \\
\hline & & WT & NT & WT & WT & NT & WT & NT & WT & NT & NT & WT & NT \\
\hline \multirow{4}{*}{0} & Control & $\mathrm{p}$ & $\mathrm{a}$ & $\mathrm{p}$ & $\mathrm{p}$ & $\mathrm{p}$ & $\mathrm{p}$ & $\mathrm{p}$ & $\mathrm{p}$ & $\mathrm{p}$ & $\mathrm{p}$ & $\mathrm{p}$ & $\mathrm{p}$ \\
\hline & Captan + Tecto & $\mathrm{a}$ & $\mathrm{a}$ & $\mathrm{a}$ & $\mathrm{a}$ & $\mathrm{p}$ & $\mathrm{a}$ & $\mathrm{p}$ & $\mathrm{p}$ & $\mathrm{p}$ & $\mathrm{a}$ & $\mathrm{a}$ & $\mathrm{a}$ \\
\hline & Derosal & $\mathrm{a}$ & $\mathrm{a}$ & $\mathrm{a}$ & $\mathrm{p}$ & $\mathrm{p}$ & $\mathrm{p}$ & $\mathrm{p}$ & $\mathrm{p}$ & $\mathrm{p}$ & $\mathrm{p}$ & $\mathrm{p}$ & $\mathrm{a}$ \\
\hline & Thiram & $\mathrm{p}$ & $\mathrm{p}$ & $\mathrm{p}$ & $\mathrm{p}$ & $\mathrm{p}$ & $\mathrm{p}$ & $\mathrm{p}$ & $\mathrm{p}$ & $\mathrm{p}$ & $\mathrm{p}$ & $\mathrm{p}$ & $\mathrm{a}$ \\
\hline \multirow{4}{*}{3} & Control & $\mathrm{a}$ & $\bar{a}$ & $\mathrm{p}$ & $\mathrm{a}$ & $\mathrm{a}$ & $\mathrm{p}$ & $\mathrm{p}$ & $\mathrm{p}$ & $\mathrm{p}$ & $\mathrm{p}$ & $\mathrm{p}$ & $\mathrm{p}$ \\
\hline & Captan + Tecto & $\mathrm{a}$ & $\mathrm{a}$ & $\mathrm{a}$ & $\mathrm{a}$ & $\mathrm{a}$ & $\mathrm{p}$ & $\mathrm{p}$ & $\mathrm{p}$ & $\mathrm{p}$ & $\mathrm{p}$ & $\mathrm{p}$ & $\mathrm{p}$ \\
\hline & Derosal & $\mathrm{a}$ & $\mathrm{a}$ & $\mathrm{p}$ & $\mathrm{a}$ & $\mathrm{a}$ & $\mathrm{p}$ & $\mathrm{p}$ & $\mathrm{p}$ & $\mathrm{p}$ & $\mathrm{p}$ & $\mathrm{p}$ & $\mathrm{p}$ \\
\hline & Thiram & $\mathrm{a}$ & $\mathrm{a}$ & $\mathrm{a}$ & a & $\mathrm{a}$ & $\mathrm{p}$ & $\mathrm{p}$ & $\mathrm{p}$ & $\mathrm{p}$ & $\mathrm{p}$ & $\mathrm{p}$ & $\mathrm{p}$ \\
\hline \multirow{4}{*}{6} & Control & $\mathrm{p}$ & $\mathrm{p}$ & $\mathrm{p}$ & $\mathrm{p}$ & $\mathrm{p}$ & $\mathrm{p}$ & $\mathrm{p}$ & $\mathrm{p}$ & $\mathrm{p}$ & $\mathrm{p}$ & $\mathrm{p}$ & $\mathrm{p}$ \\
\hline & Captan + Tecto & $\mathrm{a}$ & $\mathrm{a}$ & $\mathrm{a}$ & $\mathrm{a}$ & $\mathrm{p}$ & $\mathrm{p}$ & $\mathrm{p}$ & $\mathrm{p}$ & $\mathrm{p}$ & $\mathrm{p}$ & $\mathrm{p}$ & $\mathrm{p}$ \\
\hline & Derosal & $\mathrm{p}$ & $\mathrm{p}$ & $\mathrm{p}$ & $\mathrm{p}$ & $\mathrm{p}$ & $\mathrm{p}$ & $\mathrm{p}$ & $\mathrm{p}$ & $\mathrm{p}$ & $\mathrm{p}$ & $\mathrm{p}$ & $\mathrm{p}$ \\
\hline & Thiram & $\mathrm{p}$ & $\mathrm{p}$ & $\mathrm{p}$ & $\mathrm{a}$ & $\mathrm{p}$ & $\mathrm{p}$ & $\mathrm{p}$ & $\mathrm{p}$ & $\mathrm{p}$ & $\mathrm{p}$ & $\mathrm{p}$ & $\mathrm{p}$ \\
\hline \multirow{4}{*}{9} & Control & $\mathrm{p}$ & $\mathrm{p}$ & $\mathrm{p}$ & $\mathrm{p}$ & $\mathrm{p}$ & $\mathrm{p}$ & $\mathrm{p}$ & $\mathrm{p}$ & $\mathrm{p}$ & $\mathrm{p}$ & $\mathrm{p}$ & $\mathrm{p}$ \\
\hline & Captan + Tecto & $\mathrm{a}$ & $\mathrm{a}$ & $\mathrm{a}$ & a & $\mathrm{a}$ & $\mathrm{p}$ & $\mathrm{p}$ & $\mathrm{p}$ & $\mathrm{p}$ & $\mathrm{a}$ & $\mathrm{a}$ & $\mathrm{p}$ \\
\hline & Derosal & $\mathrm{p}$ & $\mathrm{a}$ & $\mathrm{p}$ & $\mathrm{p}$ & $\mathrm{p}$ & $\mathrm{p}$ & $\mathrm{p}$ & $\mathrm{a}$ & $\mathrm{p}$ & $\mathrm{p}$ & $\mathrm{p}$ & $\mathrm{p}$ \\
\hline & Thiram & $\mathrm{p}$ & $\mathrm{p}$ & $\mathrm{p}$ & $\mathrm{p}$ & $\mathrm{p}$ & $\mathrm{p}$ & $\mathrm{p}$ & $\mathrm{p}$ & $\mathrm{p}$ & $\mathrm{p}$ & $\mathrm{p}$ & $\mathrm{p}$ \\
\hline
\end{tabular}

* Aspergillus, Fusarium, Penicillium

Aspergillus, Fusarium and Penicillium were also observed on ripe seeds (Table 2) before storage, and only the mixture Captan+Tecto effectively controlled Fusarium and Aspergillus on seeds with a tegument. Only Fusarium and Penicillium were observed after three months of storage but no products gave effective control. After six months of storage, not only Fusarium and Penicillium were present, but also Aspergillus, which was controlled by the fungicides Captan+Tecto and Thiram on seeds with a tegument.

After nine months, only seeds treated with Captan+Tecto had no Aspergillus, while seeds with a tegument and treated with Derosal had no Penicillium. Also, as storage time increased, there was an increase in the incidence of albino seedlings, regardless of the maturation stage. There are reports that the fungus Alternaria tenuis is the most common causal agent of this mutation, followed by Aspergillus flavus, both of which produce a toxin that inhibits chlorophyll production (Laranjeira et al., 2005). Fungus species of the genera Aspergillus, Penicillium and Rhizopus can occur on seeds and their incidence can increase, causing damage and deteriorating seeds during storage (Machado, 2000), especially if the storage environment presents a high relative humidity and temperature. Also, Dhingra (1985) reported that storage fungi are the major cause of viability loss in seeds stored at a relative humidity higher than the critical level. Koller et al. (1993) observed increased fungal incidence, especially of Penicillium on treated Poncirus trifoliata seeds, stored in polyethylene bags at $35.5 \%$ moisture. In general, fungi contribute to seed deterioration during storage although 
other factors may also participate in this process.

'Swingle' citrumelo seed germination occurred, mostly from the fifth to the thirtieth day after sowing, indicating that tegument removal was efficient in promoting germination, which may take up to sixty days. Similar results were found by Oliveira (2003), for Poncirus trifoliata seeds. Slow germination may be due to mechanical barriers (Soares Filho et al., 1995), but Ramos (1991) found no effect of tegument removal on the germination of 'Cravo' and 'Trifoliata' limes.

In addition to the mechanical barrier, germination inhibition may be caused by allelochemicals present in the seed tegument. Ketring (1973) identified a citral inhibitor on Citrus limon fruits. In tests done with lettuce seeds sown on substrate moistened with ground extracts from 'Swingle' citrumelo seed testa and tegma, Carvalho (2001) observed reductions of $88 \%$ in the germination values of lettuce seeds sown in the presence of testa extract and $100 \%$ when they were sown in a substrate containing tegma extract. Souza et al. (2006) also found a reduction in the percentage germination of lettuce seeds sown in a substrate containing a 5\% tegma extract of "Swingle" citrumelo seeds and with no root hairs on their radicles.

Compared to green seeds, the germination of ripe seeds was greater at 0 month for seeds treated with the fungicides Captan+Tecto, Derosal and Thiram and at 3 months, for seeds treated with Derosal and Thiram (Table 3). This pattern changed after nine months of storage for the Captan+ Tecto treatment. Up to the sixth month, seeds subjected to fungicide treatment and collected at stage 2 (ripe) showed higher germination compared to those collected at stage 1 (green). There was better conservation of seeds obtained from green fruits in the last storage period, possibly because those seeds had not yet reached physiological maturity and preserved the membrane structure. Comparing the fungicidal treatments used, seeds treated with Captan+Tecto showed higher germination, although this treatment did not totally eradicate the pathogens. Seed germination in the ninth month was practically zero for all treatments, except for seeds extracted from green fruits and treated with Captan + Tecto, where $41 \%$ germination was observed.

TABLE 3. Germination (\%) of 'Swingle' citrumelo seeds treated and untreated with fungicides at two maturation stages, stage 1 (1) and stage 2 (2).

\begin{tabular}{|c|c|c|c|c|c|c|c|c|}
\hline \multirow{2}{*}{ Fungicide } & \multicolumn{2}{|c|}{0 months } & \multicolumn{2}{|c|}{3 months } & \multicolumn{2}{|c|}{6 months } & \multicolumn{2}{|c|}{9 months } \\
\hline & 1 & 2 & 1 & 2 & 1 & 2 & 1 & 2 \\
\hline Control & $80^{\mathrm{bA}}$ & $80^{\mathrm{bA}}$ & $41^{\mathrm{cA}}$ & $42^{\mathrm{cA}}$ & $1^{\mathrm{cB}}$ & $8^{\mathrm{cA}}$ & $0^{\mathrm{bA}}$ & $0^{\mathrm{bA}}$ \\
\hline Captan+Tecto & $88^{\mathrm{aB}}$ & $95^{\mathrm{aA}}$ & $72^{\mathrm{aA}}$ & $73^{\mathrm{aA}}$ & $48^{\mathrm{aA}}$ & $46^{\mathrm{aA}}$ & $41^{\mathrm{aA}}$ & $10^{\mathrm{aB}}$ \\
\hline Derosal & $63^{\mathrm{cB}}$ & $82^{\mathrm{bA}}$ & $40^{\mathrm{cB}}$ & $71^{\mathrm{abA}}$ & $26^{\mathrm{bA}}$ & $28^{\mathrm{bA}}$ & $0^{\mathrm{bA}}$ & $0^{\mathrm{bA}}$ \\
\hline Thiram & $71^{\mathrm{cB}}$ & $86^{\mathrm{bA}}$ & $52^{\mathrm{bB}}$ & $63^{\mathrm{bA}}$ & $1^{\mathrm{cB}}$ & $26^{\mathrm{bA}}$ & $0^{\mathrm{bA}}$ & $0^{\mathrm{bA}}$ \\
\hline
\end{tabular}

CV (\%) 9.9

Means followed by the capital and small letter in the column for each period of storage do not differ from one another by Tukey's test at the 5\% probability level.

Nevertheless, seed germination was satisfactory (about $70 \%$ ) up to three months of storage when treated with Captan + Tecto (green and ripe seeds) and with Derosal (ripe seeds).

There was a much higher incidence of pathogens on the seeds after six months of storage and this significantly affected seed germination (Table 3). No differences were found between the untreated control and green seeds treated with Thiram. Reduction in germination during storage could also be attributed to fungicide phytotoxicity. Menten (1996) stated that storage may sometimes increase phytotoxic effects and lower fungicide efficacy. Smooth surfaced seeds, such as maize, soybeans and dry beans, retain less chemical product, depending on the formulation used. In contrast, rough surfaced seeds, such as cotton, rice and wheat, allow greater chemical retention (Machado, 2000) and this was also observed for the citrus seed tegument.

The reduction in seed germination, even for treated seeds, may be due to the seed water content, since water droplets formed inside the packages. Hence, on average, $6 \%$ of treated and $10 \%$ of untreated seeds, rotted, a fact 
also reported by Kolleret al. (1993). Seeds treated with the fungicide mixture reduced fungal incidence during storage. There was a greater reduction in the germination of seeds in the control treatment and in the other fungicide treatments when compared with the fungicide mixture. Poncirus trifoliata seeds treated with Captan maintained germination for six months (Koller et al., 1993).

After nine months of storage, seeds appeared to be rotten, smelt of ethanol and the seed mass was moist, regardless of the fungicide treatment. This occurred mainly for seeds from mature fruits. Even in a cold chamber, the percentage germination of these samples was zero, except for those treated with the fungicide mixture. Also for green seeds, there was a greater reduction in germination than that observed for mature seeds when treated with the fungicide mixture. This fact could possibly be explained by the physiological dormancy or immaturity of the embryo. Seed storage in the cold chamber could have favored dormancy breakage or embryo maturation. However, citrumelo seed viability was considerably reduced during storage, confirming the difficulty of maintaining the seeds of this cultivar under such artificial conditions.

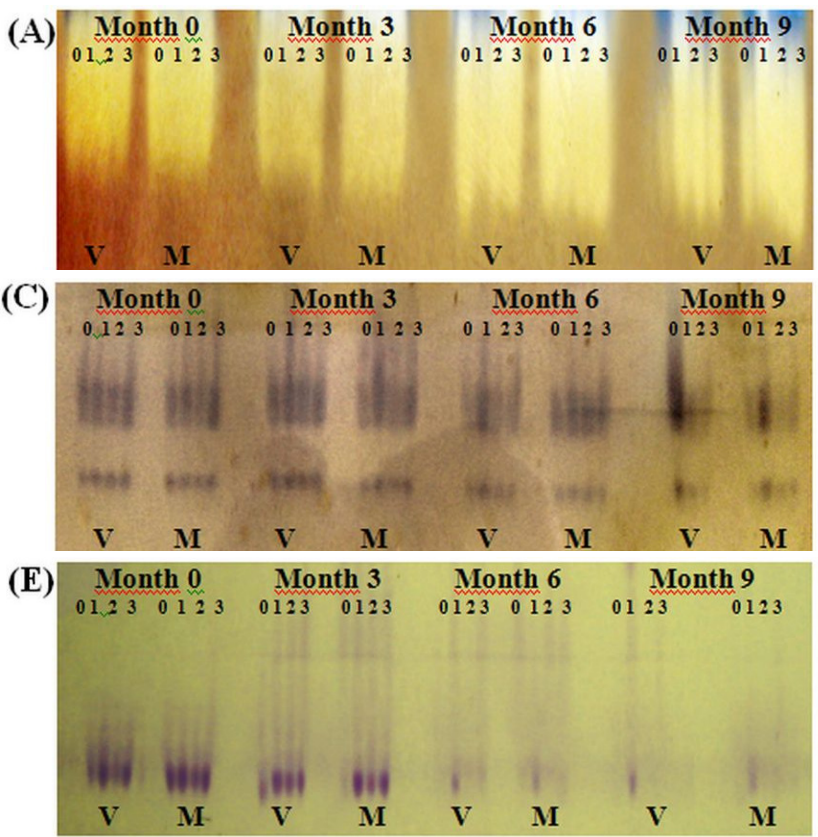

According to Roberts (1973), Citrus spp. seeds are considered troublesome from the storage viewpoint and they must be stored with more than $35 \%$ moisture content. Von Pinho et al. (2005) reported that an adequate storage of 'Swingle' citrumelo seeds requires around $40 \%$ water content for impermeable packaging in a refrigerated room. Mungomery et al. (1966) showed that 'Cleópatra' tangerine (Citrus reticulata Blanco) seed viability could be maintained during storage, provided that the seeds were maintained with a moisture content above $40 \%$ and temperatures between $5{ }^{\circ} \mathrm{C}$ and $10{ }^{\circ} \mathrm{C}$. Those authors used permeable packaging resulting in an equilibrium of the seeds with the environment, in contrast to the present study, where impermeable packaging was used and the seeds were stored at $10{ }^{\circ} \mathrm{C}$, which reinforced the recalcitrant nature of the species. Regarding the enzyme profiles of 'Swingle' citrumelo seeds, increased activity of catalase, an enzyme of the cell anti-oxidant defense system, was observed in the more advanced stages of deterioration (Figure 1A). In the fungicide treatments, greater activity was observed after six and nine months of storage and enzyme activity was more evident in mature seeds.

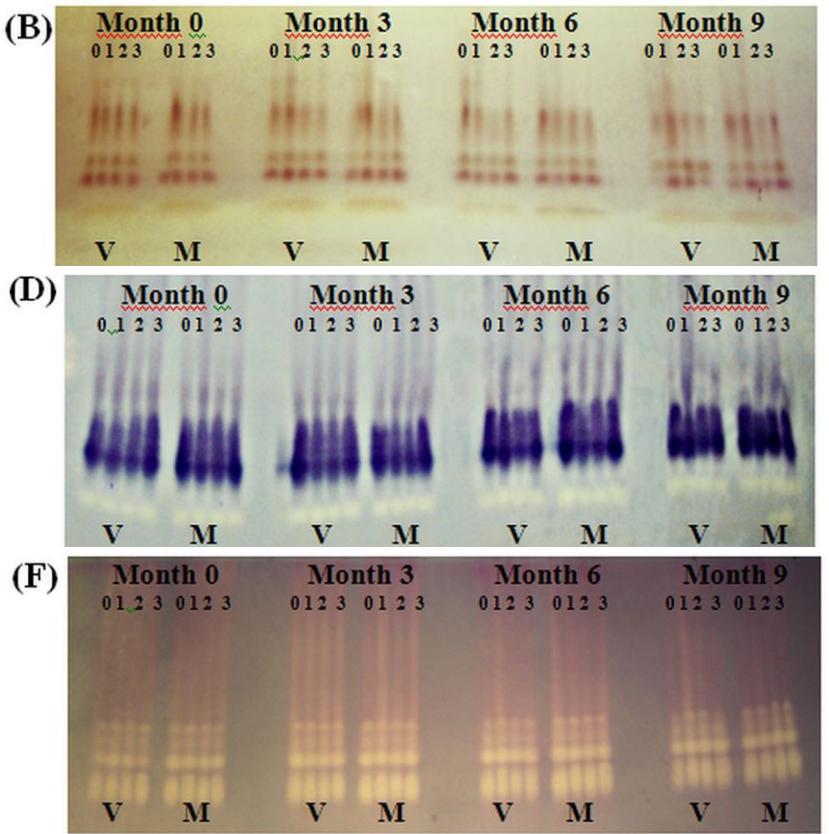

FIGURE 1. Enzyme profiles of catalase-CAT (A), esterase-EST (B), glutamate oxalacetate transaminase-GOT (C) malate dehydrogenase-MDH (D), phosphate glutamate isomerase-PGI (E), superoxide dismutaseSOD (F) of green (V), mature (M) and treated, control (0), Captan + Tecto(1), Derosal(2), Thiram(3), 'Swingle' citrumelo seeds. 
In contrast to the control, a greater activity of this enzyme was observed in seeds treated with Thiram and Derosal, probably due to the phytotoxicity of the fungicide. This may have been due to greater fungicide retention on the rough seed surface, and also to the fact that these fungicides inhibit pyruvate dehydrogenation and, at high concentrations, could act in other cell processes (Machado, 2000). Bonome (2006) found a slight increase in catalase in rubber tree (Hevea brasiliensis) seeds for up to 165 days of storage at room temperature, while for seeds stored in a cold room, this enzyme remained unchanged, regardless of the fungicide treatment. In contrast, Bailly et al. (1996) observed a decrease in enzyme activity with aging in peanut and sunflower seeds. The increase in the activity of this enzyme, followed by an increase in SOD (Figure 1F), although not in the same proportion, clearly demonstrates the inefficacy of the antioxidant system in recalcitrant seeds. This same fact was also reported by Pukacka and Ratajczak (2005) in Fagussylvatica seeds.

Greater esterase activity (Figure 1B) was found in seeds treated with Captan+Tecto, compared to the untreated control, and this was more evident in mature seeds. This activity demonstrates greater lipid peroxidation, since this enzyme is involved in the ester hydrolysis reaction and is directly associated with lipid metabolism (Santos et al., 2004). Fessel (2005) found a decrease in esterase activity with the increased aging of maize seeds. Similar results were found by Aung and McDonald (1995) in peanut seeds, for both soaked and non-soaked seeds. According to these authors, esterases are the most important group of enzymes in peanut germination and the seeds are oleaginous, containing $48 \%$ lipids (Marcos Filho, 2005). The chemical composition of 'Swingle' citrumelo seeds indicated high fat contents in both mature (35\%) and green seeds (34\%), which was determined in pre-tests performed for this study.

A decrease in microorganism proliferation on treated rubber tree seeds was observed by Bonome (2006), who also observed a reduction in the activity of this enzyme in treated embryos of this species with increasing storage time. In contrast, untreated seeds stored at room temperature had more microorganisms as the storage time lengthened, the increased esterase activity. These results support the values obtained from the germination test (Table 3).

Brandão Jr. et al. (1999) observed a lower intensity of an esterase band group and the increase in another band with corn aging, suggesting that the appearance of new bands could be due to fungal action during storage. Chauhan et al. (1985) observed that the esterase banding pattern found in soybean and barley seeds was not uniformly present in the different treatments associated with the periods of accelerated aging. The number of bands also increased with aging, with some specific bands for a given aging period.

Glutamate oxalacetate transaminase (GOT) (Figure 1C) plays an important role in protein degradation and synthesis and is of fundamental importance in seed germination. Thus, probably the increase in band number is related to greater metabolic activity. There was a decrease in GOT activity as storage progressed for seeds treated with Captan+Tecto, indicating the efficacy of the treatment.

Bonome (2006) also discovered an increase in enzyme activity in untreated seeds after 105 days' storage at room temperature, followed by a decrease. This decrease was attributed to an increased incidence in microorganisms under those conditions. These results agree with those of the present study, where a greater percentage of microorganisms was found with increasing storage time

The enzyme malate dehydrogenase (Figure 1D) reduced activity during storage, except for seeds treated with Captan+Tecto, characterizing a de-structuring of the mitochondrial membrane, with a consequent deficiency in the aerobic pathway, since this enzyme is important in the Krebs cycle for generating NADH. Even in seeds stored in plastic packages the aerobic pathway occurs, but also with some traces of the anaerobic pathway. Since the seeds were contaminated with microorganisms, an increase in respiration was expected due to the use of carbohydrate reserves, i.e., there was an increase in metabolic activity and energy was required to supply that demand. At the same time, biosynthesis and the accumulation of several compounds began, some of them directly linked to the defense mechanism. Malate dehydrogenase catalyzes the conversion of malate to oxaloacetate, and besides this important function in the Krebs cycle, participates in the transport of malate through the mitochondrial membrane and in the fixation of $\mathrm{CO}_{2}$ by the plants (Taiz, 2004). Seed treatment with Tecto+Captan was effective in maintaining the activity of this enzyme after nine months' storage, and this was confirmed by the results of tests evaluating seed physiological quality. 
Phosphoglucomutase (PGI) (Figure 1E) transforms glucose-1-phosphate into glucose-6-phosphate during glycolysis, a reaction that occurs in the cytoplasm for energy production. This sugar is phosphorilated but if it is in the form of starch or glycogen, the incorporation of phosphate occurs through the enzyme phosphorilase (Ferri, 1985). With increasing storage time, the activity of this enzyme was reduced because the sugars were used up, making this enzyme an excellent marker in the early stages of the deterioration process, since it acts in glycolysis, an early phase of the respiration process. Enzyme activity was maintained in seeds treated with Captan+Tecto, which had the lowest fungal incidence compared to all the other treatments, and also had higher germination values.

\section{CONCLUSIONS}

The treatment of 'Swingle' citrumelo seeds with Captan+Tecto is effective in pathogen control and for maintaining seed quality during storage.

Seeds extracted from green fruits deteriorated less than mature ones at nine months' storage.

At three months storage, the germination of the green and ripe seeds is satisfactory $(70 \%)$.

\section{AKNOWLEDGEMENTS}

To CNPq-Conselho Nacional Científico e Tecnológico and CAPES - Coordenação de Aperfeiçoamento de Pessoal de Nível Superior for financial support.

\section{REFERENCES}

ALFENAS, A.C.; PETERS, I.; BRUNE, W.; PASSADOR, G.C. Eletroforese de proteínas e isoenzimas de fungos e essências florestais. Viçosa: UFV, 1991. 242p.

AUNG, U.T.; MCDONALD, M.B. Changes in esterase activity associated with peanut (Arachishipogaea L.) seed deterioration. Seed Science and Technology, v.23, p.101$111,1995$.

BAILLY, C.; BENAMAR, A.; COBINEAU, F.; CÔME, $D$. Changes in malondialdehyde content and in superoxide dismutase, catalase, and glutathione reductase activities in sunflower seeds as related to deterioration during accelerated aging. Physiologia Plantarum, v.97, p.104$110,1996$.

BONOME, L.T.S. Alterações fisiológicas, bioquímicas e moleculares em sementes de seringueira (Hevea $\mathrm{sp}$.) durante o armazenamento. 2006. 136f. Tese (Doutorado em Fisiologia) - Universidade Federal de Lavras, Lavras, 2006.

BRANDÃO JUNIOR, D.S.; CARVALHO, M.L.M.; VIEIRA, M.G.G.C. Variações eletroforéticas de proteínas e isoenzimas relativas à deterioração de sementes de milho envelhecidas artificialmente. Revista Brasileira de Sementes, v.21, p.114-121, 1999.

BRASIL. Ministério da Agricultura e da Reforma Agrária. Secretaria Nacional de Defesa Agropecuária. Departamento Nacional de Produção Vegetal. Coordenação de Laboratório Vegetal. Regras para análise de sementes. Brasília, DF, 1992. 365p.

CAMACHO, O.; VALLE, V.N.DEL.; HERRERA. I.L.; CAMOS, R.A.; RIOSS, C.A.; ACOSTA, S.M.; DITA, R.M.A. Conservacion de semillas de patrones cítricos. Centro Agrícola, v.22, p.5-9, 1995.

CARVALHO, J.A. Conservação de sementes de citros e testes rápidos para avaliação da qualidade fisiológica. 2001. 140f. Tese (Doutorado em Tecnologia de Planta) Universidade Federal de Lavras, Lavras, 2001.

CHAUHAN, K.P.S.; GOPINATHAN, M.C.; BASU, C.R. Electrophoretic variation of protein and enzymes in relation to seed quality. Seed Science and Technology, v.13, p.629-641, 1985.

COHEN, A. Studies on the viability of citrus seeds and certain properties of their coats. Israel Journal of Botany, v.7, p.69-80, 1956.

DHINGRA, O.D. Prejuízos causados por microrganismos durante o armazenamento de sementes. Revista Brasileira de Sementes, v.7, p.139-145, 1985.

FERRI, M.G. (Coord.). Fisiologia vegetal. São Paulo: EPU, 1985. 362p.

FESSEL, S.A. Testes fisiológicos e eletroforese de enzimas para monitoramento da deterioração em sementes de milho. 2005. 139f. Tese (Doutorado em Fitotecnia) Universidade Estadual Paulista. Jaboticabal, 2005.

JUNIOR, J.P. Porta-enxertos. In: JUNIOR, D.M.; NEGRI, J.D.; PIO, R.M.; JUNIOR, J.P. (Ed.) Citros. Campinas: IAC/FUNDAG, 2005. Chapter 6, p.125-145.

KETRING, D.L. Germination inhibitors. Seed Science and Technology, v.1, p.305-324, 1973.

KOLLER, O.L.; STUKER, H.; VERONA, L.A.F.; SOPRANO, E. Efeito da umidade da semente, da 
temperatura de estocagem e da duração de estocagemsobre a germinação de Poncirus trifoliata e de outros portaenxertos de citros. Revista Brasileira de Fruticultura, v.15, p.27-33, 1993.

LARANJEIRA, F.F.; AMORIM, L.; FILHO, A.B.; AGUILAR-VILDOSO, C.I.; FILHO, H.D.C. Fungos, procariotos e doenças abióticas. In: JUNIOR, D.M.; NEGRI, J.D.; PIO, R.M.; JUNIOR, J.P. (Ed.) Citros. Campinas: IAC/FUNDAG, 2005. Chapter 18, p.508-566.

MACHADO, J.C. Tratamento de sementes no controle de doenças. Lavras: LAPS: UFLA: FAEPE, 2000. 138p.

MACHADO, J.C. Patologia de sementes: fundamentos e aplicações. Brasília, DF: Ministério da Educação; Lavras: ESAL/FAEPE, 1988. 177p.

MARCOS FILHO, J. Fisiologia de sementes de plantas cultivadas. Piracicaba: FEALQ, 2005. 495 p.

MENTEN, J.O.M. Tratamento químico de sementes. In: SIMPÓSIO BRASILEIRO DE PATOLOGIA DE SEMENTES, 4., Campinas, 1996. Proceedings... Campinas: Fundação Cargill, 1996. p.104.

MUNGOMERY, W.V.; AGNEW, G.W.J.; PRODONOFF, E.T. Maintenance of citrus seed viability. Queensland Journal of Agricultural and Animal Sciences, v.23, p.103-120, 1966.

OLIVEIRA, R.P.; SCIVITTARO, W.B.; RADMANN, E.B. Procedimentos para o armazenamento de sementes de Poncirustrifoliata (L.) Raf. Revista Brasileira de Fruticultura, v.25, p.461-463, dez. 2003.

PUKACKA, S.; RATAJCZAC, R. Production and scavenging of reactive oxygen species in Fagussylvatica seeds during storage at varied temperature and humidity.
Journal of Plant Physiology, v.162, p.873-885, 2005.

RAMOS, J.D.; SERGIO, A.C.; PASQUAL, M. Efeito da extração do tegumento na expressão poliembriônica de sementes de dois porta-enxertos cítricos. Revista Brasileira de Fruticultura, v.13, p.161-166, 1991.

RENA, A.B.; SIQUEIRA, D.L.; MACHADO, E.C. Fisiologia dos Citrus. In: JUNIOR, D. M.; NEGRI, J.D.; PIO, R.M.; JUNIOR, J.P. (Ed.) Citros. Campinas: IAC/ FUNDAG, 2005. Chapter 7, p. 147-195.

ROBERTS, E.H. Predicting the storage life of seeds. Seed Science and Tecnology, v.1, p.499-514, 1973.

SANTOS, C.M.R.; MENEZES, N.L.; VILELA, F.A. Alterações fisiológicas e bioquímicasemsementes de feijão envelhecidas artificialmente. Revista Brasileira de Sementes, v.26, p.110-119, 2004.

SOUZA, L. A; SILVA, T.T.A.; VON PINHO, E.V.R. ; RIBEIRO, M.N.O. Germinação de sementes de alface na presença de extratos do tegumento de sementes de citrumelo 'Swingle'. In: XV CONGRESSO DE PÓS-GRADUAÇÃO DA UFLA, 2006, Lavras. Anais.... Lavras: UFLA, 2006. CD-ROM.

SOARES FILHO, W.S.; LEE, M.; CUNHA SOBRINHO, A.P. Influence of pollinators on polyembryony in Citrus. Acta Horticulturae, v.403, p.256-265, 1995.

TAIZ, L.; ZEIGER, E. Fisiologia vegetal. 3.ed. Porto Alegre: Artmed, 2004. 719p.

VON PINHO, E.V.R.; SILVA, T.T.A.; CARVALHO, J.A.; OLIVEIRA, J.A.; GUIMARÃES, R.M. Conservação de sementes de citrumelo Swingle. Revista Brasileira de Armazenamento, v.30, p.178-185, 2005. 